\title{
12 Exemplar or Anomaly? Exiting the New Order in Comparative Perspective
}

\author{
WILLIAM CASE
}

In monitoring democracy's progress, Southeast Asia was famously evaluated during the mid-1990s as the world's most 'recalcitrant' region (Emmerson 1995). Thus, in contrast to many other parts of the world, a great variety of authoritarian and even post-totalitarian regimes endured, attributable to 'viceregal' colonial legacies, compliant cultural outlooks, divided social structures, invasive, if flabby state apparatuses, the functional requisites of late industrialisation, and, where industrialisation had taken place, the preoccupation of new middle classes with careerist and consumer pursuits. Indonesia's authoritarian politics under the New Order, a protean combination of personal, military, and singleparty rule, gained particular resilience.

But even if delayed by various forces, democracy finally arrived in Southeast Asia. In Indonesia, however deadening the New Order's legacies, democratic change commenced with student demonstrations, urban upheavals, and the resignation of President Soeharto in 1998. In the Philippines, where President Ferdinand Marcos had punctured the country's democratic record by declaring martial law, politics were re-democratised during the 1980s through 'people power'. Similarly, in Thailand, after the military overturned democracy in the 1970s, then again in the early 1990s, democracy was restored through a street level confrontation in 1992 known as 'Black May' — even if collapsing yet again in 2006, as is discussed more fully below.

Further afield, in Cambodia and East Timor, democratic assistance provided by the United Nations led to elections that could be gauged as at least partially competitive. And even where hard authoritarian regimes have survived, pressures for democracy have appeared. In Myanmar, the military government reacted to a popular upsurge in 1988 by agreeing to hold an election two years later, a contest that it was forced to repudiate after being stunned by the results. In Malaysia a reformasi movement gained pace, so invigorating the opposition 
during the 1990s that it was able to make startling electoral gains at the end of the decade. In Singapore, some journalists have claimed that the government's 'OB' (out-of-bounds) markers have been slightly relaxed, enabling them to probe more deeply into sensitive issues, within a wider context of loosening social controls. And in the absolute sultanate of Brunei Darussalam, several opposition parties have been permitted to register and mobilise constituencies.

Analysts have sometimes understood these democratic pressures as an atavistic manifestation of the colonial 'tutelage' and democratic experience that marked the early independence periods of some Southeast Asian countries, including Indonesia, the Philippines, Malaysia, and Singapore. These pressures may have sprung too from the ambiguous impact of social pluralism that hallmarks the region. On the one hand, segmented societies have seemed ripe for state controls based on divide-and-rule strategies. But they also frustrate any deep imposition of state dominance, preventing in Indonesia, perhaps, the fulfilment of what Richard Tanter once described as the New Order's 'totalitarian ambition' (Tanter 1990). Myanmar's government too has discovered the inefficacy of coercion and the need for bargaining in outlying areas populated by hardy minorities. It has also adopted a new Constitution and pledged fresh elections in 2010, however manipulated they may be. And in Thailand, during the years after the 2006 coup, social protests have mounted by furious red-shirted opponents of the military-backed government.

Moreover, severe economic crises, such as those that afflicted Indonesia, Thailand, and Malaysia during the late 1990s, and prolonged economic stagnancy, like that bedevilling the Philippines since the 1960s, have aroused middle classes from their careerist reverie and galvanised civil society organisations. External factors have grown stronger too, with Southeast Asia's having penetrated export markets in the West incurring U.S. and European demands for political and economic liberalisation, greater respect for human rights, and improvements in governance. Thus, long after democracy's third wave crested in the rest of the world, it appeared finally to have reached Southeast Asia.

However, despite democracy's progress, this chapter argues that Southeast Asia remains strongly resistant, a thesis for which Indonesia offers a good test. After three decades of authoritarian rule, Indonesia is now credited with the most robust political rights and electoral competitiveness in the region. But as we shall see, such beneficent outcomes must mainly be attributed to the weakness of social forces and the resilience of elites, greatly compromising the quality of the democracy that has resulted. In brief, while social forces may have driven democratic change in Indonesia, they soon afterward reverted to quiescence, therein succumbing to New Order legacies. In this situation, many elites have reconstituted their statuses and relations, enabling them to capture most of democracy's benefits. Elites have found that democracy helps to cement their 
dominance, further placating social forces, while warding off criticisms from the West. In simple terms, then, democracy persists in Indonesia because it sooner sustains, than challenges the standings of elites.

Elsewhere in Southeast Asia, resistance to democracy is more easily shown. To begin, where social forces have displayed greater capacity than in Indonesia, the democracy that they have brought about has only been calibrated more tightly by elites. Thus, in the Philippines, political rights have been systematically, if informally undermined, while electoral competitiveness has been dampened by cheating and violence. In Thailand, as mentioned above, democracy was nearly snuffed out altogether, with the military resorting to authoritarian reversal in late 2006, a rare event in the third wave. In Myanmar too, the military has so restricted the terms of the election that it proposes to hold that the only well-established opposition leader, Aung Sang Suu Kyi, has been barred from contesting. Further, in Singapore, Cambodia, Vietnam, and Laos, elites have faced social forces which, for a variety of reasons, have possessed less capacity still. There has been little need, then, for elites to countenance democratic change, enabling a long record of 'electoral authoritarianism' (Schedler 2006) to persist in the first two cases and forms of post-totalitarianism to emerge in the latter two. And even in Malaysia, where opposition parties made dramatic gains in an election held in March 2008, the government has since used the country's judiciary, anti-corruption agency, and police in such partisan ways that it has effectively blocked any transition.

In trying to explain this resistance to democracy in Southeast Asia, this chapter traces the patterns by which activists, possessing organised social bases, have confronted governments. It thus enumerates the variable capacities of social activists and governing elites, the modes by which transitions to democracy may take place, and the limited quality of democracy that results. In this analysis, Indonesia's experience is especially illuminating, showcasing the gains that can be made in the wake of authoritarian rule, but also the constraints that legacies of authoritarianism can steadfastly impose. Hence, its is argued here too that while favourable estimates might be made of Indonesia's democratic regime today, they are in important respects misleading. Indeed, other country cases in Southeast Asia, though earning lesser rankings, appear to possess more energised activist and social forces.

\section{When do democratic transitions take place?}

The early literature on transitions to democracy asserted the centrality of elites, with O'Donnell and Schmitter declaring that all transitions begin amid elitelevel tensions and the fracturing of authoritarian coalitions. Only after fissures 
had widened between polarised elite factions could any 'resurgence' of civil society take place (O'Donnell and Schmitter 1986). However, this logic was entrenched in the democratising experiences of Southern Europe and Latin America, regions in which military governments abetted by technocrats had taken root because of corporatist traditions and the functional imperatives of late industrialisation. In these conditions, Barbara Geddes observed that top military officers, fearful of the corrosive effects that ruling directly might have on their corporate discipline and élan, sought typically over time to cede power, enabling soft-liners among them to gain the upper hand (Geddes 1999). And unless the military had been discredited by wartime defeat, these soft-liners were able then to negotiate change in ways that modulated the transition and perpetuated their stakes in the regime that emerged afterward, hence insulating some of their prerogatives in 'reserve' domains of power. In this way, transitions in Southern Europe and South America often amounted to elite-led processes of what Samuel Huntington labelled transformation (Huntington 1991:124-42).

But as democratic transitions spread to Eastern Europe, Africa, and Asia, they affected authoritarian regimes that were operated not only by military governments, but also by single dominant parties and personal dictators. Analysts then observed correlations between different kinds authoritarianism, the kinds of transitions that took place, and the extent of democratic change that occurred (Huntington 1991:110-21; Linz and Stepan 1996:55-65). Thus, while military governments might gradually yield state power through transformations, single dominant parties tended to engage opposition elements in more even-handed bargaining. And even after any transition, these parties remained able to contest elections within newly competitive multi-party systems. Personal dictators, by contrast, had necessarily to be up-ended through rapid processes of bottom-up replacement. Having so personalised their regimes, they could find no secure domains into which to retire after a democratic transition, nor could they build independent parties through which to re-contest state power. This left them with few chips, then, with which to negotiate the transition's dynamics (Thompson 1995:ix-x).

What stands out in Southeast Asia's record, however, is that irrespective of the kind of authoritarian politics in place - whether operated by the military, a single dominant party, or a personal dictator-incumbent governments have clung tightly to power until finally forced out. In a region characterised by lesser levels of formal institutionalisation, perhaps, than some other parts of the developing world, generals and ruling politicians, just as surely as dictators and first families, have personalised their positions and powers. Indeed, in a seminal analysis of 'neo-patrimonialism', Harold Crouch elaborated the ways in 
which these sub-types of authoritarianism were fused in New Order Indonesia, with sundry institutions and procedures deployed arbitrarily, yet skilfully, by Soeharto.

Thus, at various intervals in the New Order's record, different elements might gain prominence, including 'financial generals', 'bureaucratic families', Golkar professionals, Soeharto's own progeny, and rent-seeking cukong. But though statuses and relations might have been reconfigured as the New Order evolved, these elites never showed any willingness to transform their regime in democratic ways. Similar resistance was evident in the Philippines, Thailand, Malaysia, and Myanmar, whatever the combination of generals, dominant parties, and dictators that prevailed. Thus, more than in other parts of the developing world, where transitions to democracy have occurred in Southeast Asia, they have required bottom-up replacements, instigated by vitalised segments of the middle class and urban poor.

Southeast Asia's record is also distinctive in another way. With activists based in civil society organisations or movements galvanising socio-economic classes or ethnic communities, then driving transition-by-replacement, it might reasonably be anticipated that the changes they have promoted would be farreaching. The new democracies that result would thus be imbued with high quality, measurable first in terms of a procedural dimension of robust political rights and electoral competitiveness, and secondly on a substantive dimension of policy responsiveness, made manifest in trans-class redistributions. In this trajectory, with national leaders swept away and elites left scurrying for cover, there would seem to be little need for activists to bargain over democracy's terms or to guarantee soft landings for those they displace.

However, democracy's record in Southeast Asia defies this logic. After transitionby-replacement occurs, social activists either lose steam spontaneously or they are effectively contained by elites. Accordingly, we will see that in Indonesia, where the capacity of activists and the student groups and labour unions that they lead having weakened, hence supporting few demands for transclass redistributions, resilient elites have abided political rights and electoral competitiveness. But even where activists have shown greater capacity, as in the Philippines and Thailand, elites have reacted by truncating procedural quality. Hence, elites have in most of our Southeast Asian cases negated democracy's substantive quality. And apart from Indonesia, they have eroded procedural quality too. In explaining these patterns, let us turn now to the ways in which the separate capacities of activists and governments might be evaluated. 


\section{Assessing social forces}

With transitions in Southeast Asia amounting to bottom-up replacements, questions over their timing, dynamics, and progress must begin with the variable capacities of activists and the organisations or movements through which they galvanise classes or communities. To understand these capacities, they may be disaggregated in terms of participatory outlooks, solidary relations, and credibility as alternatives. The extent to which they score highly on these measures bears implications, though not always straightforward, for democratic change and quality.

To begin, social forces may or may not possess the dispositions with which to challenge incumbent governments and authoritarian regimes, attitudes that at the polar ends of a continuum can respectively be cast as participatory or quiescent (Case 2002:24-25). During the last decade of the New Order, the outlooks of social activists in Indonesia grew more participatory, especially among students and the urban poor. And for even longer periods of time they can be understood as participatory in the Philippines and Thailand. Accordingly, in these country cases, social forces were predisposed to support transition-by-replacement. By contrast, in Singapore, social forces have remained quiescent, hence limiting their role in politics to mild consultations over problem solving. Much of this activity has been conducted through officially sanctioned 'feedback units' and 'non-constituency MPs', chosen by the government from among housebroken opposition parties.

Next, even where characterised by participatory outlooks, social activists may be hindered by the class and communal affiliations with which Southeast Asia bristles, producing broad patterns that can respectively be understood as solidary or dispersed. Thus, where activists lack solidarity, transitions to democracy are at first delayed, then fail to yield quality. In Indonesia, for example, ethnic, religious, and regional rivalries have long divided social forces. This helped to inhibit democratic change until activists, backed by groups of students and urban poor, were finally animated by economic crisis in 1998, hence producing one of the last major transitions of the third wave. What is more, as this change unfolded, ethnic tensions grew so inflamed that while the violence that resulted may have helped in ousting Soeharto, activists were prevented from gaining the solidarity afterward with which to raise democracy's quality. In neighbouring Malaysia, though activists, middle classes, and Islamic groups were similarly enlivened by economic crisis, their reformist activities failed to drive democratic change. And even though opposition parties made unprecedented electoral headway a decade later, social forces have remained so fragmented by ethnic and religious suspicions that the government has been able to contain them. By contrast, in the Philippines and Thailand, where societies 
have mostly been lauded during the post-War period for their benign communal relations, transitions to democracy took place much earlier than in Indonesia. Moreover, in perpetuating their solidarity, activists generated greater pressures to raise democracy's quality, enabling them at least initially to win land reform and development schemes for their constituencies.

Finally, even where social activists are participatory and solidary, questions may arise over the capacity of the opposition leaders and parties that they support to graduate from merely challenging an incumbent government to offering realistic alternatives (Aspinall 2005:239-68). On this measure, capacity ranges from 'credible' to 'non-viable'. In Indonesia, though Amien Rais galvanised students in opposition to Soeharto, then later formed a party with which to contest elections, he was never regarded by the country's middle class as a capable successor. And if other parties were evaluated as more worthy, we shall see that they sooner sought their own co-optation than any serious advances in the quality of democracy by which to benefit their constituencies. By contrast, after Marcos was ousted in the Philippines, Corazon Aquino won over the middle classes and the poor through her imagery of reformism and personal sacrifice, yet also reassured the business community through her landowner status. In Thailand, Thaksin gained credibility among the rural poor and business community alike, combining populist appeals with vast family wealth and shrewd market techniques. Thus, in the Philippines and Thailand, after democratic change had occurred, leaders and parties widely evaluated as credible were brought to power. And indeed, they tried afterward to make good on the trans-class redistributions that they had promised.

In sum, where classes and communities are participatory in their outlooks, the social activists that they support seek democratic change. Where they are solidary in their relations, they make this change more quickly and pursue quality more avidly. And where they emerge as credible alternatives, they may gain state power after change has taken place, then respond with the trans-class redistribution that raise democracy's quality. But whatever the capacity that these activists may possess, this trajectory can be halted at various junctures when governments react by demonstrating far greater capacity still.

\section{Assessing governments}

The capacity possessed by governments in resisting pressures for democratic change can also be disaggregated, yielding measures of elite-level cohesion, useable state apparatuses, and absorptive regime types. In many Southeast Asia countries, governments operated by political, economic, and military elites have perpetuated or regenerated cohesive relations, enabling them to stand 
firm before societal challenges. Singapore demonstrates this configuration best, distinguished by a long record of leadership paramountcy and the orderly patterns of elite renewal. In Malaysia, further, though cohesion has been threatened episodically by elite rivalries and factional warring, each time it has been restored through leadership resurgence and the purging of rivals. Thus, pressures for democratic change have been stopped cold in Singapore and turned back in Malaysia.

In New Order Indonesia, though, and in the Philippines and Thailand too, national leaders who were weakened by economic crises, external pressures, or personal infirmities grew less able to manage elites. And as elite-level cohesion dissolved and support bases shrank, these leaders were brought down and democratic change took place. What distinguishes Indonesia, however, and Southeast Asia more generally is that this erosion in leadership skills and elite loyalties only gained pace after social forces had grown participatory. Thus, in Indonesia, once Soeharto had been battered by economic shocks and social violence, elites began to war openly, encouraging some of them to abandon him. Only then did they begin to appeal to the societal discontents that had accumulated beforehand (Aspinall 2005:202-38). In the Philippines, Marcos was similarly discredited by economic stagnation and the exposure of his electoral cheating, encouraging military elites to defect to the people power movement that opposed him. And in Thailand, the military's reckless seizure of state power in 1991, followed by violent confrontation with protesters, so alienated other political elites that they too appealed to fast-gathering social forces, prompting the king to coax the military back into the barracks. Accordingly, in these three country cases, where elite disunity prevailed, social forces were able to drive transition-by-replacement.

Governments are also able to prevent democratic change, however, where the elites who operate them are braced by a 'useable' state apparatus. Such administrative armatures are made up of bureaucratic agencies that can extract resources and implement complex policies, as well as security forces that are 'hierarchical' in their command structures and effective in applying coercion (Linz and Stepan 1996:11, 66-68). In Malaysia, then, the bureaucracy has for decades carried out programs of 'reverse' discrimination, known collectively as the New Economic Policy, enabling the government to modulate social forces by favouring the 'indigenous' Malays over 'immigrant' communities of Chinese and other ethnic affiliations. In addition, the security forces include large numbers of special branch officers and riot police, enabling the government to neutralise dissidents and crush protesters.

In New Order Indonesia, the Philippines, and Thailand, however, state apparatuses were less useable. Thus, the bureaucracies operated respectively by Soeharto, Marcos, and sundry military leaders in Thailand, riddled deeply 
with inefficiencies and corrupt practices, remained incapable of carrying out anything like Malaysia's social transformation. And in resorting more fully to coercion, these leaders had to rely upon security forces that were sharply divided across training academies, graduating class years, generational cohorts, regional commands, and services. Thus, when the point was reached in tipping games where authoritarian regimes were poised to undergo change, governments in Indonesia, the Philippines, and Thailand found that when trying to resist, their state apparatuses had grown unreliable.

But it is not just the inconsistencies in state apparatuses that may diminish the capacities of governments trying to resist pressures for democracy. Turning from bureaucratic incentives to coercive strategies can in itself fuel these pressures, with brutal coercion and the depletion of resources that might otherwise be used for development worsening societal discontents. In New Order Indonesia, the use of police operatives and street thugs to destroy the headquarters of the opposition Indonesian Democracy Party (Partai Demokrasi Indonesia, PDI) in 1996, an event commemorated as Grey Saturday, is often identified as the beginning of the end for Soeharto. The abductions and executions of left-wing dissidents under Marcos, actions known curiously as 'salvagings', fuelled a corrosive undercurrent of social resentment. And in Thailand, the military's bloody suppression of protesters in the streets of Bangkok in 1992, popularly labelled as 'Black May', only stiffened the opposition of the middle classes and urban poor.

Thus, these governments failed to gain capacity from more 'absorptive' regime types they might have operated which, in providing a measure of political space to the social forces that oppose them, can efficiently dispel participatory pressures. In particular, we recall the electoral authoritarianism practiced in Malaysia and Singapore, cunningly restricting political rights, but regularly holding elections, even reasonably competitive ones, thereby containing in vacuous assemblies the opposition parties thrown up by social forces. Instead, governments in New Order Indonesia, under Marcos in the Philippines, and in Thailand during the 1980s operated more exclusionary regimes, denoted respectively by a manipulable electoral college, a phoney impromptu parliament, and an unelected prime minister and appointed upper house. And made brittle, then, by their exclusionary character, these regimes added little capacity to governments trying to resist democratic change.

Thus, where governments are operated by elites who are cohesive, they are usually geared to resisting democratic change. Where they are firmed by useable state apparatuses, they may mount this resistance effectively. And where they are availed of absorptive regimes, they may gain new efficiencies, taming the opposition parties and leaders that had emerged as credible alternatives. But 
where governments falter on these measures, transition-by-replacement may then be advanced by activists who, buoyed up by social forces, possess their own capacity.

\section{Instigating and avoiding transition-by- replacement}

In considering the respective capacities of activists and governments, we find that in Southeast Asia, where social forces have been uncorked, activists have gained the upper hand, enabling democratic change to take place. But where governments have prevailed, various forms of authoritarian rule have persisted. Thus, there have been no modulated processes of concession-making and topdown transformation in the region, the usual pathway to democracy in Southern Europe, Latin America, and parts of Northeast Asia. Rather, where transitions have occurred, they have always begun as bottom-up replacements, even if later gaining momentum from the elite-level defections that they trigger. As we have seen, with elites having personalised state power in Southeast Asia, whether anchored in political, economic, or military sectors, they must in varying measure be pushed from their perches.

In Singapore, then, where social activists have mostly remained quiescent, dispersed, and unable to produce credible alternatives, they have been overwhelmed by the government, one that has been fortified with elite-level cohesion, highly useable state apparatuses, and to the extent still necessary, an absorptive regime. We find many of these same features in Malaysia. Though activists have been far less quiescent in this case, they have been more deeply dispersed by ethnic and religious rivalries. And hence, though often operating long-standing opposition parties, these activists have only been found credible by the separate communities that have spawned them. Indeed, even the results of the election in 2008 have been interpreted by most analysts as turning less on any new and widespread confidence in the opposition than on the protest votes that were cast against the government. Thus, while in Malaysia the government's elite-level cohesion has episodically waned and its popular support has sagged, it has each time been able to recover drawing deeply upon a useable state apparatus and the absorptive properties of its electoral authoritarianism.

Elsewhere in Southeast Asia, though, social activists gained enough capacity to drive transitions to democracy. Among our country cases in which this trajectory unfolded, activists in New Order Indonesia remained most modestly endowed, slow to grow participatory, unable to maintain solidarity, and unconvincing in their portrayals as alternative leaders. Even so, their capacity grew strong enough that as the government was at the same time weakened by elite disunity, the non- 
useability of its state apparatus and the brittleness of its regime became plain. In these conditions, activists were able to impose transition-by-replacement. In the Philippines and Thailand, activists sooner grew participatory and became more solidary. They also produced civil society organisations and opposition parties that made them more credible as alternatives. Thus, with governments in these cases just as enfeebled by elite-level disunity, unreliable state apparatuses, and exclusionary regimes as they were in Indonesia, democratic change occurred even earlier.

In the next section of this chapter, we will also see that in the Philippines and Thailand, with social activists having gained greater capacity than in New Order Indonesia, they not only drove the transition to democracy sooner, but also went further in trying to raise democracy's quality. Demands for change thus went beyond the procedural thresholds associated with political rights and electoral competitiveness to seek substantive redistributions of power and assets across class lines. Hence, in Southeast Asia's democratic experience, one of the features that most distinguishes Indonesia involves the comparative modesty of the capacity of its activists and social forces, attributable by most accounts to the New Order's legacies of steadfast controls (see Aspinall, this volume). But this, of course, poses a great puzzle: why is the quality of democracy higher in Indonesia today than anywhere else in Southeast Asia?

\section{Democracy, quality, and persistence}

Because the transitions to democracy that have occurred in Southeast Asia have nearly always been bottom-up, it might be expected that they would be far-reaching. With social activists that were participatory, solidary, and credible having triumphed over governments that were weakened by elite-level factionalism, shaky state apparatuses, and brittle regime types, they might be counted upon to keep up their pressure. In this way, democracy's quality would be raised, with new governments making the procedural changes necessary for safeguarding political rights and electoral competitiveness. Indeed, these governments might be pressed to go further, allowing more substantive changes through greater policy responsiveness, made manifest in trans-class redistributions of resources and assets.

But in Southeast Asia, though social activists may in some cases have overturned authoritarian rule, their subsequent efforts to raise democracy's quality have fallen short in one of two ways. In a first pattern, while they gained enough capacity to advance the transition to democracy, they have afterward lost vigour. With the co-operative links and fronts between their civil society organisations unravelling, social forces fell back into old postures of quiescence and dispersion. 
Moreover, opposition leaders and parties, though having earlier demonstrated credibility as alternatives, now plotted their own deep co-optation in hopes of getting a shot at state largesse.

Meanwhile, many political, economic, and military elites from the prior authoritarian period, after sacrificing the ruler and his most prominent hardliners, reconstituted their statuses and relations. They then obliged many of the opposition party elites thrown up by transitional dynamics, enmeshing them in widening patterns of collusion. Together, these old and new elites were also aided by the weaknesses that persisted in the state apparatus, enabling them to retain their bastions of privilege in key agencies and enterprises, while avoiding accountability and sanctions for their abuses. Paradoxically, then, though low levels of usability and hierarchy in the bureaucracy and military had earlier hampered old elites in their efforts to turn back transition-by-replacement, they helped these elites after the transition to renew or perpetuate their standings.

In these conditions, with the capacity of activists diminished, governments were confronted by few demands for the substantive quality that would involve the trans-class redistribution of their resources and assets. But accordingly, they tolerated increases in procedural quality, marked by fuller political rights and electoral competitiveness. Indeed, where procedural quality could be raised in isolation from substantive quality, elites found it useful for their survival. Not only were the social forces that once took to the streets corralled more safely in NGOs and multi-layered assemblies, but elites extended their legitimating cover, helping shield them from local and international criticisms. This configuration, wherein procedural quality was raised because substantive quality was kept low, accords with recent experience in Indonesia.

In a second pattern, social activists remained more participatory and solidary. Thus, they made fuller use of the political rights and electoral competitiveness that connote procedural quality to press for the trans-class redistributions associated with substantive quality. But where new national leaders duly responded with policy changes, they impinged on the prerogatives of political, economic, and military elites, prompting these elites to roll back democratic gains, even resorting to military coups. In these cases, then, it was not just substantive quality that was lost. Elites either truncated democracy's procedural quality, limiting political rights and competitiveness, or they carried out authoritarian reversal, finally ousting an elected government. These trajectories square respectively with the political records of the Philippines under Corazon Aquino and Thailand under Thaksin Shinawatra.

In the rest of this chapter, Indonesia's record will be more fully recounted alongside that of the Philippines and Thailand. What stands out is that with social forces more constrained by authoritarian legacies in Indonesia than in 
the other country cases, they have not pressed so strongly to raise democracy's quality that elites have struck back. Thus, with so few gains having been made in substantive quality, those that had registered on the procedural dimension have been preserved. In this situation, Indonesia's political rights and electoral competitiveness are evaluated as the most robust in Southeast Asia today - a ranking that must ironically be ascribed to the weakness of social forces and the resilience of elites.

\section{Indonesia: high procedural quality}

While social activists have driven all three of Southeast Asia's transitions to democracy, they remained relatively underpowered in Indonesia, a posture attributed to the oppressive legacies of New Order rule. Thus, while a range of civil society organisations and movements grew more participatory during the mid-1990s, they failed to gain solidarity. Student groups thus stood alone in softening the government up, while it was finally left to rioters and looters to deliver the decisive blow. Further, their energies spent, violent elements quickly dispersed. And after Soeharto stood down, even student groups fragmented over their differences in aims and strategies.

To be sure, some opposition leaders and parties had put themselves forward as credible alternatives to Golkar, the government's long-time electoral vehicle. But as Aspinall explains, their credibility lay in mere name recognition, traceable to their lowly functioning in the New Order's electoral system (that is, PDI and the Islamic United Development Party [Partai Persatuan Pembangunan, PPP]) or to their Islamic probing of Soeharto's abusive leadership (National Awakening Party [Partai Kebangkitan Bangsa, PKB] and National Mandate Party [Partai Amanat Nasional, PAN]) (Aspinall 2005; Aspinall this volume). Either way, these ostensible opposition parties, having been reared as little more than 'OPPs' (electoral participant organisations) and given but shallow roots in the 'floating mass', lent little weight to democratic change. And after the transition to democracy had taken place, the smallness of their appetite for reform was made plain by their more quickly seeking their own co-optation than any trans-class redistributions by which to favour the constituencies to which they appealed.

In these circumstances, as Robison and Hadiz have shown, once Soeharto, his offspring, and his most intimate cronies had been sidelined, many other political, military, and economic elites were able to reconstitute their statuses and relations (Robison and Hadiz 2005; Hadiz 2003). However seriously dislocated, then, by the loss of Soeharto's managerial skills and inflows of foreign investment, political elites were still buoyed by a tattered bureaucracy and party system; economic elites by their state monopolies and frayed conglomerates; and military elites by 
their far-flung command structure and dubious business activities. Moreover, while this configuration grew swollen by the inclusion of new elites thrown up by the transition, and though patronage was diminished by the economic crisis and administrative decentralisation, it re-established much of the cohesion, or at least forbearance, that had characterised elite-level relations under the New Order. In important ways, then, the capacity acquired by social activists was bested by elites who regenerated their cohesion, discovered opportunities in the weaknesses of the state apparatus, and found new efficiencies in the greater absorptiveness that democracy affords.

Accordingly, with elites in Indonesia facing few pressures to raise the substantive quality of democracy that derives from trans-class redistributions, they acquiesced in, indeed made use of, gathering procedural quality. Political rights and electoral competitiveness now placated, rather than activated, Indonesia's social forces, and they more broadly extended legitimating cover. Thus, according to the Freedom House survey in 2005, conducted even before Thailand's authoritarian reversal a year later, Indonesia scored highest in Southeast Asia in terms of political rights (Piano and Puddington 2006:120-24). Press freedoms were greater than they had been in Thailand under Thaksin, and they were more safely exercised than in the Philippines. Further, the competitiveness of elections was evaluated as high, with Golkar losing its legislative majority in 1999, while an incumbent president, Megawati Sukarnoputri, was defeated in 2004.

Alone in Southeast Asia, then, Indonesia's politics earned from Freedom House a ranking of 'free'. Even so, we recognise that democracy's procedural quality may only have persisted in Indonesia because it brought so little substantive quality, therein enabling elites more efficiently to perpetuate their standings. Civil society organisations and movements have lapsed into postures of quiescence and dispersion, while opposition leaders and parties, however credible as alternatives, have most urgently sought their co-optation-default modes that have carried over from New Order strategies of de-politicisation.

\section{The Philippines and Thailand: democracy's low quality, authoritarian reversal}

Given the levels of participation, solidarity, and credibility possessed by social activists in the Philippines and Thailand, varying inversely with the elitelevel disunity and deteriorating state apparatuses and regime types operated by governments, we would expect transitions-by-replacement to be more far- 
reaching in these cases than in Indonesia. After transitions took place, social forces might build upon their countries' prior democratic experiences to make new gains in both procedural and substantive quality.

Such progress began to unfold in the Philippines during the late 1980s. Most notably, with activists remaining participatory and solidary after transition had taken place, the political rights and electoral competitiveness associated with procedural quality were enshrined in a new Constitution. But more significantly, the new national leader, Corazon Aquino, demonstrated policy responsiveness by proposing land reforms, amounting to the trans-class redistributions that signify substantive quality.

At the same time, though, the country's political and economic elites, many of whom Marcos had had at least partially dispossessed of their standings, worked feverishly to reconstitute their statuses and relations. Thus, they soon reasserted their dominance over the Philippine Congress. They wrested control too over many of the monopolies in commodities production and trading that Marcos had arranged for his cronies. And upon finding their prerogatives threatened by trans-class redistributions, these elites used their influence and resources to roll back the gains that had been made in substantive quality. In particular, we note the many bloody coup attempts that took place under Aquino, appearing closely to correlate with periods in which her government tried most seriously to implement land reform measures. Indeed, only when the reforms were wound down toward the end of her tenure did the drumbeat of coups fade away. Even so, the elites took no chances, keeping the lid on social forces by truncating procedural quality too. Thus, while political rights and electoral competitiveness may be officially guaranteed, they have remained tenuous in practice. In the Philippines, journalists are bribed, threatened, and frequently murdered, while elections have invariably been marred by cheating and local violence.

Similarly, in Thailand, we would expect that after transition took place, social activists that had grown participatory and solidary would seek to raise democracy's quality. Thus, after two false starts in the mid-1970s and late 1980s, with democracy each time cut short by military coups, significant gains in procedural quality were made after a third transition in the early 1990s, leading to the crafting of a highly reformist Constitution. Moreover, if some of these gains were compromised after Thaksin Shinawatra gained power through competitive elections in 2001, new advances in substantive quality were registered through his government's highly innovative policy responsiveness, made manifest in a range of redistributive programs that included village-level micro-credit, a debt moratorium for cultivators, and cheap medical care.

But by mobilising rural masses in ways that greatly bolstered his personal appeal and electoral prospects, Thaksin encroached upon the peasant constituencies so 
cherished by the monarchy and military as central to their nation-building lore. He more directly challenged the military too by cultivating factional loyalties and influencing promotions. Thus, in carrying out their coup in late 2006, though the military's leaders sought justification in Thaksin's corrupt practices and the recklessness of his strategies in the country's southern Malay provinces, they seem much sooner to have been motivated by his contesting their corporate prerogatives and the monarch's social grounding, an institution with which they have in recent decades been closely allied. Accordingly, while some of Thaksin's social programs have been left in place, at least for the time being, the military has stamped out political rights and electoral competitiveness, then consented only to limited political reopening. Not content merely to truncate democracy's procedural and substantive quality as in the Philippines, the military has first carried out full authoritarian reversal.

\section{Conclusions}

In 1984, Harold Crouch published an important analysis entitled Domestic Political Structures and Regional Economic Co-operation (Crouch 1984). In it, he developed a set of matrices by which to produce multi-causal explanations of the extent to which the governments of ASEAN countries might engage one another over regional policy making. Across his country cases, Crouch investigated developmental levels, social structures, and elite- and mass-level pressures, enabling him to gauge variations in government performance.

This chapter draws inspiration from Crouch's comparative analysis. But rather than using local variables to predict cross-national outcomes, the framework deployed here has focused more simply on democratic change and quality within discrete country cases. Thus, in turning first to the social forces and the capacity they possess, participatory outlooks, solidary relations, and credible alternatives were explored. Then, on the government side of the ledger, elite-level cohesion, useable state apparatuses, and absorptive regime types were addressed. In Southeast Asia, the contests that social activists and governments then wage have in most cases tipped in the government's favour, thereby perpetuating authoritarian rule. But among these cases, this chapter gave special attention to Singapore and Malaysia, countries in which, because of rapid industrialisation and new middle-class formations, the dynamics by which authoritarianism have nonetheless endured may yield new insights into how governments resist pressures for democracy.

In a few country cases in Southeast Asia, however, democratic change has taken place, enabling us to draw additional lessons. First, in New Order Indonesia, the Philippines, and Thailand, change has occurred where social activists have 
prevailed, yielding a pattern of transition-by-replacement which, in its regionwide scope, distinguishes Southeast Asia's experience. Second, while such transitions might be expected to yield high levels of quality, made manifest by gains on a procedural dimension of political rights and electoral competitiveness, followed by those on substantive indices of trans-class redistributions, progress has rarely been straightforward. Such expectations fail to anticipate that even where social forces triumph over governments, enabling democratic change to go forward, governments may afterward regenerate capacity, then roll back democracy's progress. Most crucially, elites who have lost cohesion may show resilience, reconstituting their statuses and relations.

Thus, in the Philippines, though democracy was brought about through a momentous transition, its quality was afterward run down. In Thailand, democracy has undergone authoritarian reversal, even if some of the earlier gains made in substantive quality have been left intact. But it is democracy's contrary progress in Indonesia today that remains most intriguing. Here, political rights and electoral competitiveness have flourished, emerging as the most robust in Southeast Asia. Freedoms of communication and assembly are thus respected by the government, producing a lively media and a thriving community of civil society organisations and political parties. Furthermore, elections are regular, meaningful, and free of systematic fraud or violence, generating turnovers in presidential and parliamentary contests. At least some of the New Order's dark legacies, then, would appear to have lifted, confounding most predictions.

Yet, though casual observers may take heart, a closer inspection reveals that conditioning by the New Order has not fully abated. Social activists in Indonesia, having reverted to postures of quiescence and diffusion, remain weaker than their counterparts in the Philippines and Thailand. And while the government in Indonesia may also remain hobbled by the limited useability of its state apparatus, it has at the same time regenerated much elite cohesion, enabling it to exploit the absorptive capacities of the new, more democratic regime that it now operates.

Indeed, this chapter has argued that while social activists have remained consistent on all three indices of capacity (participatory outlooks, solidary relations, and credible alternatives), they are today overmatched by a government that has recovered on two fronts (elite-level cohesion and regime absorptiveness). In this situation, citizens are unable to make such concerted use of their political rights and electoral competitiveness that they can press effectively for trans-class redistributions. Rather, the government remains better able to exploit democracy's procedural quality, notching up the legitimacy that dispels both local and international criticisms, even while parrying demands for substantive quality. However, by the readings of Freedom House, Indonesia 
Soeharto's New Order and its Legacy

is still better off. Though citizens may not fully exercise their political rights or avail themselves of electoral competitiveness, they are at least informed of the inequalities that elites still impose upon them. 